\title{
KECERDASAN EMOSI, RELIGIUSITAS DAN KEPUASAN PERNIKAHAN PADA WANITA MUSLIM YANG MENIKAH MUDA
}

\author{
Fina Mokoginta \\ UIN Syarif Hidayatullah Jakarta \\ finalforfinal@gmail.com
}

\begin{abstract}
The purpose of this research was to know the effect of emotional intelligence and religiousity towards marital satisfaction on muslim woman that married young. 210 muslim woman in Jakarta and Bogor within 18-21 years old with 5-10 years old marriage was used as sample in this research. The data collected using questionnaire to measure emotional intelligence with Trait Emotional Intelligence Questtionnaire-Short Form, religiousity with Religious Commitment Inventory-10, and marital satisfaction with ENRICH Marital Satisfaction. The data analyzed using multiple regression in 0.05 significancy. The result showed that there was a significant effect of emotional intelligence and religiousity towards marital satisfaction. Variance proportions from marital satisfaction explained by emotional intelligence and religiousity with percentage 55\%. Age in marriage has a significant effect toward marital satisfaction.
\end{abstract}

Keywords: Marital Satisfaction, Emotional Intelligence, Religiousity

\begin{abstract}
Abstrak
Penelitian ini dilakukan untuk mengetahui pengaruh kecerdasan emosi dan religiusitas terhadap kepuasan pernikahan pada wanita muslim yang menikah muda. Sampel dalam penelitian ini adalah 210 wanita muslim yang menikah di usia 18-21 tahun dengan lama usia pernikahan 5-10 tahun, tinggal di daerah Jakarta dan Bogor. Pengumpulan data dilakukan dengan pengisian kuesioner untuk mengukur kecerdasan emosi dengan Trait Emotional Intelligence Questionnaire-Short Form, mengukur religiusitas dengan Religious Commitment Inventory-10, dan untuk mengukur kepuasan pernikanan menggunakan ENRICH Marital Satisfaction. Analisis data yang digunakan adalah analisa regresi berganda pada taraf signifikansi 0,05. Hasil penelitian menunjukkan bahwa ada pengaruh yang signifikan antara kecerdasan emosi dan religiusitas terhadap kepuasan pernikahan. Proporsi varians dari kepuasan pernikahan yang dijelaskan oleh faktor kecerdasan emosi dan religiustas adalah sebesar 55\%..Begitu juga dengan usia pernikahan memiliki pengaruh signifikan terhadap kepuasan pernikahan.
\end{abstract}

Kata Kunci: Kepuasan Pernikahan, Kecerdasan Emosi, Religiusitas

Diterima: 5 Januari 2014 Direvisi: 2 Februari $2014 \quad$ Disetujui: 10 Februari 2014 


\section{PENDAHULUAN}

Menikah muda adalah ikatan lahir batin antara seorang pria dengan wanita sebagai suami istri di usia remaja akhir (18-21 tahun) (Monks, dalam Mutadin, 2002). Dalam hubungan dengan hukum menurut UU, usia minimal untuk suatu pernikahan adalah 16 tahun untuk wanita dan 19 tahun untuk pria (Pasal 7 UU No. 1/1974 tentang perkawinan). Jelas bahwa UU tersebut menganggap orang di atas usia tersebut bukan lagi anak-anak sehingga mereka sudah boleh menikah. Batasan usia ini dimaksud untuk mencegah pernikahan terlalu dini. Walaupun begitu, selama seseorang belum mencapai usia 21 tahun, masih diperlukan izin orang tua untuk menikahkan anaknya. Setelah berusia di atas 21 tahun, boleh menikah tanpa izin orang tua (Pasal 6 ayat 2 UU No. 1/1974). Tampaklah di sini, bahwa walaupun UU tidak menganggap mereka yang di atas usia 16 tahun untuk wanita dan 19 tahun untuk pria bukan anak-anak lagi, tetapi belum dianggap memiliki kedewasaan yang penuh. Sehingga masih perlu izin untuk menikahkan mereka.

Kedewasaan seseorang sangat berhubungan erat dengan usianya, usia remaja akhir memperlihatkan keadaan jiwa yang selalu berubah. Selain belum penuhnya kedewasaan pada usia remaja akhir, pernikahan yang dilakukan di usia tersebut juga dikatakan "muda" karena belum terselesaikannya jenjang pendidikan mereka. Pada umumnya juga mereka belum cukup memiliki pengetahuan dan keterampilan, sehingga hal tersebut memengaruhi sulitnya mendapatkan pekerjaan dengan penghasilan yang memadai.

Di Indonesia perkawinan usia muda berkisar $12-20 \%$ yang dilakukan oleh pasangan baru. Biasanya, perkawinan usia muda dilakukan pada pasangan usia muda usia rata-rata umurnya antara 16-20 tahun. Secara nasional perkawinan usia muda dengan usia pengantin di bawah usia 16 tahun sebanyak 26,95\%. Hasil Sensus Penduduk 2010 menunjukkan bahwa persentase pemuda perempuan dengan status kawin lebih tinggi dibandingkan dengan pemuda laki-laki $(57,60 \%$ berbanding $39,35 \%)$. Sebaliknya, persentase pemuda laki-laki yang belum kawin $(59,81 \%)$ lebih tinggi dibandingkan pemuda perempuan (40,33\%). Perbedaan kedua angka ini secara tidak langsung menunjukkan bahwa perempuan pada umumnya menikah di usia lebih muda dibandingkan dengan laki-laki (BPS, 2010a).

Bila dilihat dari tipe daerah, data statistik menunjukkan bahwa perempuan dan laki-laki di perdesaan (64,10\% dan 41,65\%) memiliki 
kecenderungan untuk menikah lebih awal dibandingkan dengan perempuan dan laki-laki di perkotaan (51,48\% dan 36,65\%). Dilihat dari hasil Sensus Penduduk 2010 yang dilakukan Badan Pusat Statistik (2010b), pernikahan di usia muda terbanyak berada di Provinsi DKI Jakarta dan Jawa Barat. Hasil Sensus Penduduk dikedua Provinsi tersebut juga memperlihatkan hasil yang sama, bahwa perempuan pada umumnya menikah di usia lebih muda dibandingkan dengan laki-laki.

Pernikahan di usia muda pada zaman sekarang ini sudah jarang terjadi. Kebanyakan para pemuda baik laki-laki maupun perempuan cenderung enggan melakukan pernikahan di usia muda. Hal ini disebabkan oleh banyak hal, yang intinya pada ketidak siapan dari para pemuda untuk menjalankannya. Banyak dari mereka berasumsi bahwa menikah di usia muda akan menghambat berbagai pencapaian yang belum mereka raih. Menikah muda juga dianggap berpengaruh pada kepuasan pernikahan yang rendah, yang rentan akan konflik hingga berujung pada perpisahan.

Fakta menunjukkan bahwa ada sebuah pergeseran trend usia rata-rata anak muda menikah di Indonesia, yang walaupun pelan tapi pasti, dari usia rata-rata yang lebih muda, menuju usia yang lebih tua. Bahkan, bila kita melihat data historikal pada anak muda yang tinggal di pedesaan, trend pergeseran yang sama juga terlihat. Pada hasil sensus penduduk tahun 1971, usia rata-rata wanita perkotaan Indonesia menikah adalah 21,1 tahun. 34 tahun kemudian, di tahun 2005 usia rata-rata ini bergeser ke 24,6 tahun. Sementara untuk pria perkotaan, yang pada tahun 1994 usia rata-rata menikahnya adalah 27,2 tahun, bergeser ke 27,9 di tahun 2005 (Kartajaya \& Kristofel, J. 2010).

Penelitian yang dilakukan Patterson \& Kim pada 1990-an menyatakan, ada beberapa alasan mengapa orang memutuskan untuk menikah. Ternyata, posisi pertama (alasan terbanyak) adalah cinta (36\%). Alasan kedua, meneruskan hubungan yang sudah terjalin (14\%). Alasan ketiga, untuk memiliki anak (12\%). Alasan keempat, menganggap pernikahan adalah jalan untuk mencapai kebahagiaan atau alasan ingin berbahagia (9\%). Alasan kelima cukup konotatif, yaitu karena uang (5\%). Alasan keenam, karena pernikahan sudah menjadi kebiasaan (5\%). Alasan ketujuh, karena ingin menggantungkan diri dan hidup dengan pasangan (3\%). Alasan yang berada di posisi paling akhir adalah karena takut terkena AIDS (2\%) (Kartajaya dan Kristofel, 2010).

Dalam menjalani pernikahan, kepuasan dalam pernikahan sangatlah dibutuhkan untuk keberlangsungan pernikahan tersebut. Kepuasan 
pernikahan adalah penilaian subjektif dan bersifat dinamis oleh pasangan suami istri mengenai kehidupan pernikahan mereka. Kepuasan pernikahan dapat diukur dengan melihat aspek-aspek dalam perkawinan sebagaimana yang dikemukakan oleh Fowers \& Olson (1989; 1993).

Hasil penelitian menunjukkan bahwa kepuasan pernikahan yang rendah dapat menurunkan kesehatan psikologis, meningkatkan stres psikologis (Ross, Mirowsky, \& Goldsteen, dalam Prasetya, 2007), serta berkorelasi dengan meningkatnya depresi terutama pada wanita (Dehle \& Weiss, dalam Prasetya, 2007). Ditemukan juga bahwa pengaruh kepuasan pernikahan terhadap kesehatan berbeda antara pria dan wanita. Seperti terungkap dalam penelitian yang dilakukan oleh Hess \& Soldo (dalam Prasetya, 2007) bahwa pria yang telah menikah tampak lebih sehat daripada pria lajang baik bagi mereka yang pernikahannya membahagiakan ataupun tidak. Tetapi hal ini tidak berlaku bagi wanita. Pada wanita, mereka yang telah menikah terlihat memiliki kesehatan psikologis yang lebih tinggi dibandingkan wanita yang belum menikah "hanya" bila pernikahan mereka bahagia. Mengingat hal inilah penulis merasa lebih tertarik untuk meneliti kepuasan pernikahan pada wanita, yang tampaknya lebih membutuhkan perhatian dibandingkan kepuasan pernikahan bagi kaum pria.

Secara teoritis, kepuasan pernikahan memiliki hubungan dengan kecerdasan emosi dan religiusitas. Di mana secara umum tinggi rendahnya kecerdasan emosi seseorang akan memengaruhi tinggi rendahnya kepuasan pernikahan. Tinggi rendahnya kecerdasan emosi dapat dipengaruhi oleh usia, yang umumnya semakin menginjak usia dewasa, semakin baik kecerdasan emosinya. Individu yang memiliki kemampuan mengelola emosi akan lebih cakap menangani ketegangan emosi, karena kemampuan mengelola emosi ini akan mendukung individu menghadapi dan memecahkan konflik interpersonal dan kehidupan secara efektif.

Begitu juga dengan religiusitas yang memiliki hubungan dengan kepuasan pernikahan. Religiusitas dapat diartikan sebagai pernyataan seseorang yang mempercayai Tuhan, ditandai dengan kesalehan dan semangat keagamaannya. Semakin tinggi kesalehan dan semangat keagamaannya, maka semakin kuat keyakinannya kepada Tuhan, semakin tinggi religiusitasnya (Salleh, 2012). Religiusitas dianggap memiliki peran dalam kepuasan pernikahan, karena religiusitas seseorang dapat memengaruhi pola pikir dan perilakunya dalam menjalani kehidupan pernikahan. Tinggi rendahnya tingkat religiusitas seseorang, akan memengaruhi tinggi rendahnya kepuasan pernikahan yang dirasakan. Pada 
umumnya, semakin tinggi tingkat religiusitas seseorang, semakin tinggi juga kepuasan pernikahan tersebut. Jane (dalam Nihayah, Adriani \& Wahyuni, 2013) menyatakan bahwa kepercayaan terhadap agama memiliki pengaruh yang sangat besar terhadap kepuasan pernikahan jangka panjang.

Penelitian ini penting untuk diteliti karena banyaknya permasalahan yang bahkan berujung pada perceraian yang terjadi dalam pernikahan yang dilakukan di usia muda. Untuk itu peneliti mencoba untuk melihat pengaruh kecerdasan emosi dan religiusitas terhadap kepuasan pernikahan pada wanita muslim yang menikah muda, dengan melakukan penelitian yang berjudul "Kecerdasan Emosi, Religiusitas dan Kepuasan Pernikahan pada Wanita Muslim yang Menikah Muda."

\section{METODE}

\section{Partisipan}

Sampel dalam penelitian ini berjumlah 210 orang, yang dipilih secara accidental. Sampel diambil di daerah Jakarta Timur, dan Cisarua, Bogor. Peneliti menentukan sampel berdasarkan individu yang sesuai dengan kriteria yang telah ditentukan oleh peneliti. Kriteria sampel dalam penelitian ini adalah wanita muslim, menikah saat berusia 18-21 tahun, usia pernikahan 5-10 tahun dan bersedia menjadi responden dalam penelitian ini. Sampel yang bersedia menjadi responden diminta untuk mengisi kuesioner. Kuesioner dapat diisi dan dikembalikan langsung kepada peneliti. Tapi ada sebagian kuesioner yang dikembalikan pada peneliti beberapa hari setelahnya. Setelah pengembalian kuesioner, peneliti memberikan reward berupa buku saku seputar pernikahan islami dan keluarga sakinah. Terkumpulnya jumlah sampel sebanyak 210 orang diperlukan waktu satu bulan lamanya.

\section{Pengukuran}

Kepuasan Pernikahan. Skala yang digunakan untuk mengukur kepuasan pernikahan adalah ENRICH Marital Satisfaction (Blaine J. Fowers \& David H. Olson, 1993). ENRICH Marital Satisfaction terdiri atas 15 item dan setelah dilakukan uji validitas semua item valid. Dalam uji validitas konstruk skala kepuasan pernikahan, peneliti menggunakan analisis CFA (Confirmatory Factor Analysis) yang dilakukan dengan model satu faktor. Selanjutnya peneliti melihat apakah signifikansi item tersebut mengukur faktor yang hendak diukur, sekaligus menentukan apakah item tersebut 
perlu didrop atau tidak. Maka dilakukan pengujian hipotesis nihil tentang koefisien muatan faktor dari item. Pengujiannya dilakukan dengan melihat nilai t bagi setiap koefisien muatan faktor. Hasil pengujian terlihat bahwa seluruh item memiliki koefisien bermuatan positif dan signifikan, yaitu memiliki nilai $t>1,96$ yang berarti semua tidak ada yang di drop. Selain itu, peneliti juga melihat apakah item-item tersebut saling berkorelasi, yang artinya item-item tersebut multidimensional. Langkah terakhir yaitu itemitem kepuasan pernikahan yang tidak didrop dihitung skor faktornya. Skor faktornya dihitung untuk menghindari estimasi bias dari kesalahan pengukuran. Jadi perhitungan skor faktor ini tidak menjumlahkan item-item variabel seperti pada umumnya, tetapi dihitung true score pada tiap skala. Skor faktor yang dianalisis adalah skor faktor yang bermuatan positif dan signifikan adapun rumus T Score. Setelah didapatkan skor faktor yang telah diubah menjadi $\mathrm{T}$ score, nilai baku inilah yang akan dianalisis dalam uji hipotesis korelasi dan regresi.

Kecerdasan Emosi. Skala yang digunakan untuk mengukur kecerdasan emosi adalah Trait Emotional Intelligence Questionnaire-Short Form (TEIQue$S F$ ) (Petrides \& Furnham, 2003). TEIQue-SF terdiri atas 30 item yang semuanya valid setelah dilakukan uji validitas. Dalam uji validitas konstruk skala kecerdasan emosi, peneliti menggunakan analisis CFA (Confirmatory Factor Analysis) yang dilakukan dengan model satu faktor. Kecerdasan emosi dalam penelitian ini terbagi menjadi empat dimensi, yaitu emotionality, selfcontrol, sociability, dan well-being. Hasil analisis CFA emotionality yang kemudian dimodifikasi terhadap model, di mana kesalahan pada beberapa item dibebaskan berkorelasi satu sama lainnya, maka diperoleh model fit dengan Chi-Square $=44.62, \mathrm{P}$-value $=0.06826, \mathrm{RMSEA}=0.043$. Sementara self-control diperoleh model fit dengan Chi-Square $=3.52$, P-value $=0.61978$, RMSEA $=0.000$. Sedangkan sociability diperoleh model fit dengan Chi-Square $=10.59, \mathrm{P}$-value $=0.10198, \mathrm{RMSEA}=0.060$. Dan wellbeing diperoleh model fit dengan Chi-Square $=10.30, \mathrm{df}=8, \mathrm{P}$-value $=$ 0.24432 , RMSEA $=0.037$. Dari hasil pengujian hipotesis nihil, item yang dimiliki dari empat dimensi kecerdasan emosi seluruhnya memiliki nilai $t>$ 1,96 yang berarti semua tidak ada yang didrop. Dari hasil matrik korelasi antar kesalahan pengukuran juga tidak ada item yang dikeluarkan, artinya tidak ada yang tidak diikutsertakan dalam analisis perhitungan faktor.

Religiusitas. Skala yang digunakan untuk mengukur religiusitas adalah Religious Commitment Inventory-10 (Worthington, 2003). RCI-10 terdiri atas 
10 item, setelah dilakukan uji validitas diperoleh hasil seluruh item valid. Dalam uji validitas konstruk skala religiusitas, peneliti menggunakan analisis CFA (Confirmatory Factor Analysis) yang dilakukan dengan model satu faktor. Religiusitas dalam penelitian ini terbagi menjadi dua dimensi, yaitu interpersonal religious commitment (komitmen religius interpersonal) dan intrapersonal religious commitment (komitmen religius intrapersonal). Hasil analisis CFA interpersonal religious commitment (komitmen religius interpersonal) yang kemudian dimodifikasi terhadap model, di mana kesalahan pada beberapa item dibebaskan berkorelasi satu sama lainnya, maka diperoleh model fit dengan nilai Chi-Square $=1.09, \mathrm{P}$-value $=$ 0.29710 , RMSEA $=0.020$. Sementara intrapersonal religious commitment (komitmen religius intrapersonal) diperoleh model fit dengan nilai ChiSquare $=8.69$, P-value $=0.12220$, RMSEA $=0.059$. Dari hasil pengujian hipotesis nihil, item yang dimiliki dari dua dimensi religiusitas seluruhnya memiliki nilai $t>1,96$ yang berarti semua tidak ada yang didrop. Dari hasil matrik korelasi antar kesalahan pengukuran juga tidak ada item yang dikeluarkan, artinya tidak ada yang tidak diikutsertakan dalam analisis perhitungan faktor.

\section{Analisa Statistik}

Untuk mengukur pengaruh kecerdasan emosi dan religiusitas terhadap kepuasan pernikahan, maka pengolahan data pada penelitian ini menggunakan analisis statistik Mutiple Regression Analysis (Analisis Regresi Berganda). Melalui regresi berganda ini dapat diperoleh nilai $\mathrm{R}$, yaitu koefisien korelasi berganda antara kepuasan pernikahan dengan kecerdasan emosi dan religiusitas. Besarnya variasi kepuasan pernikahan yang disebabkan oleh faktor-faktor yang telah disebutkan tadi ditunjukkan oleh koefisien determinasi berganda atau $\mathrm{R}^{2}$. $\mathrm{R}^{2}$ merupakan proporsi varians dari kepuasan pernikahan yang dijelaskan oleh kecerdasan emosi dan religiusitas. Kemudian untuk menguji apakah pengaruh yang diberikan variabel-variabel independent signifikan terhadap dependent variable maka peneliti melakukan uji $t$. 
HASIL

Tabel 1

Karakteristik Sampel Penelitian $(N=210)$

\begin{tabular}{lc}
\hline \multicolumn{1}{c}{ Karakteristik } & $\mathbf{n}(\mathbf{\%})$ \\
\hline Usia Menikah & $25(11.91)$ \\
18 & $44(20.95)$ \\
19 & $50(23.81)$ \\
20 & $91(43.33)$ \\
21 & \\
Usia Pernikahan & $62(29.52)$ \\
5 & $27(12.86)$ \\
6 & $15(7.14)$ \\
7 & $21(10)$ \\
8 & $19(9.05)$ \\
9 & $66(31.43)$ \\
10 & \\
Usia Saat Ini & $12(5.71)$ \\
23 & $30(14.28)$ \\
24 & $29(13.81)$ \\
25 & $35(16.67)$ \\
26 & $21(10)$ \\
27 & $31(14.76)$ \\
28 & $18(8.57)$ \\
29 & $20(9.52)$ \\
30 & $14(6.67)$ \\
31 & \\
Pendidikan & $19(9.05)$ \\
SMP & $72(34.28)$ \\
SMA & $65(30.95)$ \\
D3 & $44(20.95)$ \\
S1 2 & $10(4.76)$ \\
Rendah $<49.99$ & $85(40.5)$ \\
Tinggi $>49.99$ & $125(59.5)$ \\
\hline
\end{tabular}

\section{Analisa Regresi}

Dari hasil penelitian multiple regression diperoleh $R^{2}$ sebesar 0,550 atau 55\%. Artinya proporsi varians dari kepuasan pernikahan yang dijelaskan oleh semua independent variable adalah sebesar 55\%, sedangkan $45 \%$ sisanya dipengaruhi oleh variabel lain di luar penelitian ini. 
Tabel 2

Tabel Anova

\begin{tabular}{llrrrrr}
\hline Model & & \multicolumn{1}{c}{$\begin{array}{c}\text { Sum of } \\
\text { Squares }\end{array}$} & Df & $\begin{array}{l}\text { Mean } \\
\text { Square }\end{array}$ & F & Sig. \\
\hline \multirow{2}{*}{1} & Regression & 10208.419 & 7 & 1458.346 & 35.259 & $.000^{\mathrm{b}}$ \\
& Residual & 8354.997 & 202 & 41.361 & & \\
\hline & Total & 18563.416 & 209 & & & \\
\hline
\end{tabular}

Tabel 1 menunjukkan bahwa nilai $\mathrm{p}$ (Sig.) pada kolom paling kanan adalah 0,000 atau $p=0,000$ dengan nilai $p<0,05$, maka hipotesis nihil yang menyatakan tidak ada pengaruh yang signifikan seluruh independent variable terhadap kepuasan pernikahan ditolak. Artinya, ada pengaruh yang signifikan dari kecerdasan emosi, religiusitas dan usia pernikahan terhadap kepuasan pernikahan pada wanita muslim yang menikah muda.

Tabel 3

Koefisien Regresi

\begin{tabular}{|c|c|c|c|c|c|c|}
\hline \multirow{2}{*}{\multicolumn{2}{|c|}{ Model }} & \multicolumn{2}{|c|}{$\begin{array}{c}\text { Unstandardized } \\
\text { Coefficients }\end{array}$} & \multirow{2}{*}{$\begin{array}{l}\text { Standardized } \\
\text { Coefficients } \\
\text { Beta }\end{array}$} & \multirow[t]{2}{*}{$\mathbf{t}$} & \multirow[t]{2}{*}{ Sig. } \\
\hline & & B & Std. Error & & & \\
\hline \multirow{8}{*}{1} & (Constant) & 3.800 & 3.722 & & 1.021 & .309 \\
\hline & Emotionality & .347 & .078 & .330 & 4.439 & $.000 *$ \\
\hline & Self-Control & .001 & .076 & .001 & .014 & .989 \\
\hline & Sociability & .066 & .061 & .062 & 1.083 & .280 \\
\hline & Well-Being & .392 & .069 & .375 & 5.707 & $.000^{*}$ \\
\hline & $\begin{array}{l}\text { Religius } \\
\text { Interpersonal }\end{array}$ & .002 & .089 & .002 & .022 & .983 \\
\hline & $\begin{array}{l}\text { Religius } \\
\text { Intrapersonal }\end{array}$ & . 188 & .086 & .177 & 2.201 & $.029 *$ \\
\hline & $\begin{array}{l}\text { Usia } \\
\text { Pernikahan }\end{array}$ & -.477 & .223 & -.106 & -2.141 & $.033^{*}$ \\
\hline
\end{tabular}

a. Dependent Variable: KEPUASAN PERNIKAHAN, sig* $<0.05$

Dari tabel 2 dapat dilihat bahwa terdapat empat variabel yang berpengaruh signifikan terhadap kepuasan pernikahan yaitu emotionality, well-being, religius intrapersonal, dan usia pernikahan.

\section{DISKUSI}

Berdasarkan uji hipotesis utama yang dilakukan dengan menggunakan uji multiple regression, maka penelitian ini dapat disimpulkan bahwa ada pengaruh bersama yang signifikan antara kecerdasan emosi, religiusitas, dan 
usia pernikahan terhadap kepuasan pernikahan pada wanita muslim yang menikah muda.

Pada kecerdasan emosi, aspek emotionality dan well-being memiliki pengaruh positif yang signifikan. Sementara aspek self-control dan sociability memiliki pengaruh positif namun tidak signifikan terhadap kepuasan pernikahan pada wanita muslim yang menikah muda.

Religiusitas pada aspek komitmen religius intrapersonal memiliki pengaruh positif yang signifikan. Sementara aspek komitmen religius interpersonal memiliki pengaruh positif namun tidak signifikan terhadap kepuasan pernikahan pada wanita muslim yang menikah muda.

Faktor demografis pada penelitian ini yaitu usia pernikahan memiliki pengaruh negatif yang signifikan terhadap kepuasan pernikahan pada wanita muslim yang menikah muda.

Faktor pengaruh terbesar yang signifikan terhadap kepuasan pernikahan pada wanita muslim yang menikah muda adalah emotionality dari kecerdasan emosi dengan pengaruh positif dan terbesar kedua adalah well-being dari kecerdasan emosi yang juga memiliki pengaruh positif.

Dari hasil penelitian ini, ditemukan bahwa terdapat beberapa faktor psikologis yang dinilai berpengaruh terhadap kepuasan pernikahan pada wanita muslim yang menikah muda, diantaranya sebagai berikut:

1. Hasil penelitian ini menunjukkan bahwa kecerdasan emosi berperan dalam munculnya kepuasan pernikahan.

a. Emotionality dari kecerdasan emosi memiliki pengaruh positif dan signifikan. Hasil penelitian ini menunjukkan bahwa, semakin tinggi emotionality, atau semakin wanita dapat memahami tentang perasaannya juga perasaan orang lain, mampu mengkomunikasikan perasaannya pada orang lain, mampu memiliki hubungan pribadi, mampu mengambil sudut pandang orang lain, maka semakin tinggi pula kepuasan pernikahan yang dirasakan. Bradbury, Fincham \& Beach (dalam Waldinger, Hauser, Schulz, Allen \& Crowell, 2004) menyatakan bahwa emotionality adalah faktor utama dalam melihat kepuasan pernikahan. Mengekspresikannya juga memiliki implikasi untuk kepuasan pernikahan. Dalam penelitian yang mereka lakukan, didapatkan kesimpulan bahwa emotionality berhubungan secara signifikan dengan kepuasan pernikahan.

b. Well-being dari kecerdasan emosi memiliki pengaruh positif dan signifikan. Hasil penelitian ini menunjukkan bahwa, semakin wanita merasa bahagia, puas dengan hidupnya, sukses, percaya diri, dan 
dapat melihat sisi baik dalam kehidupan, maka semakin tinggi pula kepuasan pernikahan yang dirasakan. Sejalan dengan penelitian Glen (dalam Ningsih, 2013) menunjukkan bahwa individu yang telah menikah secara konsisten menunjukkan well-being yang lebih besar dari yang tidak pernah menikah dan individu yang sebelumnya pernah menikah (bercerai, dipisahkan atau janda). Selain itu juga penelitian ini sejalan dengan penelitian yang dilakukan oleh Proulx, Helms \& Buehler yang menyatakan bahwa terdapat hubungan yang signifikan antara well-being dengan kepuasan pernikahan.

2. Hasil penelitian menunjukkan bahwa religiusitas berperan dalam munculnya kepuasan pernikahan.

a. Religiusitas intrapersonal memiliki pengaruh yang positif dan signifikan. Hasil penelitian ini menunjukkan bahwa, semakin wanita menjalankan nilai-nilai agamanya, yakin, dan mengaplikasikan semuanya dalam kehidupan sehari-hari, maka semakin tinggi pula kepuasan pernikahan yang dirasakan. Sejalan dengan penelitian yang dilakukan Jane, juga Filsinger \& Wilson (dalam Nihayah, Adriani \& Wahyuni, 2013) yang menyatakan bahwa kepercayaan terhadap agama memiliki pengaruh yang sangat besar terhadap pernikahan jangka panjang, dan agama juga memiliki peran dalam perkawinan dengan membuat pasangan menjadi lebih puas. Selain itu, berdasarkan penelitian Dudley \& Kosinski menemukan bahwa terdapat hubungan yang signifikan antara religiusitas dan kepuasan pernikahan. Bahkan secara spesifik ditemukan oleh Haseley (2006) dalam penelitiannya, bahwa terdapat hubungan yang signifikan antara religiusitas dengan kepuasan pernikahan pada wanita. Dalam penelitian Nihayah, Adriani \& Wahyuni (2013) pun didapat kesimpulan bahwa pada wanita religiusitas memberikan pengaruh yang signifikan terhadap kepuasan pernikahan. Wanita yang memiliki pengetahuan agama yang baik, akan melakukan segala sesuatu berdasarkan pengetahuannya mengenai nilai-nilai agama. Mereka akan menyadari setiap konsekuensi yang akan diterima akibat perilakunya. Hal inilah yang memungkinkan mereka untuk lebih puas dengan pernikahannya. Hal ini juga sangat berpengaruh terhadap perannya sebagai istri, yang turut serta dalam membentuk keluarga, menjadi pendidik dasar bagi anak, dan berdampak dalam kepuasan pernikahan yang dirasakan. 
3. Faktor demografis dalam penelitian ini adalah usia pernikahan atau lama menikah, yang memiliki pengaruh negatif yang signifikan terhadap kepuasan pernikahan. Hasil penelitian ini menunjukkan bahwa, semakin lama jumlah tahun sepasang suami istri telah menikah, maka semakin rendah kepuasan pernikahan tersebut.

Hal ini dapat dikarenakan dalam penelitian yang dilakukan peneliti, usia sampel saat ini berkisar antara 23-31 tahun. Pada kisaran usia tersebut, bisa jadi sampel belum mengalami tahap melepas anak. Sebagaimana dalam banyak penelitian (Vaillant \& Vaillant, 2006) yang menyatakan bahwa kepuasan pernikahan berbentuk seperti kurva U, di mana peningkatan kepuasan pernikahan terjadi ketika orangtua sudah melepas anak-anaknya.

Hal ini juga didukung oleh pendapat Hurlock (dalam Jahja, 2011) yang membagi masa dewasa menjadi tiga bagian, yakni masa dewasa awal (young adult), masa dewasa madya (middle adulthood), dan masa dewasa lanjut (older adult). Usia 22-31 tahun masuk dalam kategori masa dewasa awal. Masa dewasa awal adalah masa pencarian kemantapan dan masa reproduktif, yaitu suatu masa yang penuh dengan masalah dan ketegangan emosional, periode isolasi sosial, periode komitmen dan masa ketergantungan, perubahan nilai-nilai, kreativitas dan penyesuaian diri pada pola hidup yang baru. Oleh karena itu terdapat kemungkinan besar bahwa dalam periode ini kepuasan pernikahan akan semakin menurun seiring bertambah lamanya usia pernikahan tersebut.

Penelitian Glenn, Vaillant \& Vaillant (dalam Prasetya, 2007) menunjukkan bahwa kepuasan pernikahan berupa kurva yang menurun tajam setelah usia 10 tahun pernikahan. White and Booth juga menemukan dalam penelitian mereka bahwa kepuasan pernikahan dialami paling tinggi pada saat awal pernikahan, lalu menurun secara bertahap di tahun-tahun selanjutnya.

Penurunan kepuasan pernikahan ini mungkin berhubungan dengan hilangnya passionate love setelah pasangan menikah dalam waktu lama. Penelitian membuktikan bahwa passionate love mengalami penurunan beberapa tahun setelah perkawinan, terutama setelah terjadinya peristiwaperistiwa penting dalam keluarga seperti kelahiran anak (Tucker \& Aaron dalam Prasetya, 2007). Bagi wanita, perubahan ini akan lebih kuat terasa mengingat tanggung jawab pengasuhan lebih banyak diserahkan kepada wanita. 
Oleh karena itu hasil menunjukkan bahwa semakin lama usia pernikahan yang dijalani, akan terjadi penurunan dalam kepuasan pernikahan.

Untuk saran teoritis, diharapkan dalam penelitian selanjutnya peneliti mencari variabel lain, yang terdapat kemungkinan akan memberikan pengaruh yang signifikan terhadap kepuasan pernikahan seseorang. Untuk saran praktis, khususnya bagi para wanita di usia muda yang akan menikah, diharapkan mengikuti pelatihan, bimbingan, training atau seminar yang dapat meningkatkan kecerdasan emosi dan religiusitas agar lebih baik, sehingga akan berdampak baik pula dalam mencapai kepuasan pernikahan.

\section{DAFTAR PUSTAKA}

Adhim, M.F. (2002). Indahnya pernikahan dini. Jakarta: Gema Insani. Adiyo, R. (2010). Beberapa faktor psikologis yang memengaruhi prestasi belajar mahasiswa di bidang statistik 1\&2. Universitas Islam Negri Syarif Hidayatullah Jakarta. Skripsi tidak diterbitkan.

Al Farisi, M.Z. (2008). When i love you: menuju sukses hubungan suami istri. Jakarta: Gema Insani Press.

Al-Iraqi, B.A. (2006). Rahasia pernikahan bahagia. (terj. Muflih Kamil). Jakarta: Griya Ilmu.

Andisti, M.A., \& Ritandiyono. (2008). Religiusitas dan perilaku seks bebas pada dewasa awal. Jurnal psikologi, Vol.2, No.1, 170-176.

Ardhianita, I., \& Andayani, B. (2005). Kepuasan pernikahan ditinjau dari berpacaran dan tidak berpacaran. Jurnal psikologi, Vo.2, No. 32, 101111.

Badan Pusat Statistik. (2010a). Statistik pemuda indonesia 2010. Jakarta: CV. Petratama Persada.

Badan Pusat Statistik. (2010b). Statistik pemuda provinsi DKI Jakarta. Jakarta: CV. Petratama Persada.

Badan Pusat Statistik. (2010c). Statistik pemuda provinsi Jawa Barat. Jakarta: CV. Petratama Persada.

Bird, G., \& Melville, K. (1994). Families and intimate relationships. United States: McGraw-Hill.

Clarrochi, J., Forgas, J. P., \& Mayer, J. D. (2001). Emotional intelligence in everyday life a scientific inquiry. United States of America: Psychology Press.

Fowers B. J., \& Olson D. H. (1993). ENRICH marital satisfaction scale: a brief research and clinical tool. Journal of family psychology, Vol. 2, No.7, 176-185. 